\title{
STEREOTIP MAHASISWA MINANGKABAU TERHADAP MAHASISWA SUKU ACEH
}

\author{
Yolla Novita Putri, Anismar ${ }^{1)}$ \\ ${ }^{1}$ Program Studi Ilmu Komunikasi Universitas Malikussaleh, anismarkomnimal@yahoo.co.id
}

\section{ABSTRACT}

This study entitled Stereotypes of Minangkabau Students towards Acehnese Students (Study of Minangkabau Students). This research focuses on the stereotypes that Minangkabau students have towards Acehnese students and the stereotypical factors. Stereotypes are overly generalized, too easy, simplified or exaggerated beliefs about a group. The purpose of this study is to find out what stereotypes Minangkabau students have towards Acehnese students and the stereotypical factors that Minangkabau students have towards these Acehnese students. This study uses a descriptive qualitative approach using the theory of symbolic interactionism. To get accurate data and informants, the data collection techniques used in this study were observation, interviews, and documentation. The results showed that stereotypes of Minangkabau students towards Acehnese students were dominated by negative stereotypes.

Keywords: Minangkabau Students, Acehnese Students, Stereotypes, Symbolic Interactions

\begin{abstract}
ABSTRAK
Penelitian ini berjudul Stereotip Mahasiswa Minangkabau terhadap Mahasiswa Suku Aceh (Studi pada Mahasiswa Minangkabau). Penelitian ini berfokus kepada stereotip yang dimiliki oleh mahasiswa Minangkabau terhadap mahasiswa suku Aceh serta faktor terbentuknya stereotip tersebut. Stereotip merupakan keyakinan yang terlalu digeneralisasikan, terlalu dibuat mudah, disederhanakan atau dilebihlebihkan mengenai suatu kelompok. Tujuan dari penelitian ini adalah untuk mengetahui stereotip apa saja yang dimiliki oleh mahasiswa Minangkabau terhadap mahasiswa suku Aceh dan faktor penyebab dari stereotip yang dimiliki mahasiswa Minangkabau terhadap mahasiswa suku Aceh tersebut. Penelitian ini menggunakan pendekatan kualitatif bersifat deskriptif dengan menggunakan teori interaksionisme simbolik. Untuk mendapatkan data dan informan yang akurat maka teknik pengumpulan data yang digunakan dalam penelitian ini adalah observasi, wawancara, dan dokumentasi. Hasil penelitian menunjukkan stereotip yang dimiliki mahasiswa Minangkabau terhadap mahasiswa suku Aceh didominasi oleh stereotip negatif.
\end{abstract}

Kata Kunci: Mahasiswa Minangkabau, Mahasiswa Suku Aceh, Stereotip, Interaksi Simbolik 


\section{PENDAHULUAN}

Aceh merupakan wilayah yang memiliki keberagaman suku dan budaya, baik suku pribumi maupun suku pendatang. Hidup dalam keberagaman ini terkadang menghasilkan stereotip diantara mereka. Hal itu tidak hanya terjadi di tengah masyarakat, tetapi juga ditemukan di dalam lingkup komunitas pendidikan. Mahasiswa yang kuliah di sebuah universitas tidak hanya berasal dari daerah sekitar universitas tersebut seperti yang terjadi di Universitas Malikussaleh. Mahasiswa banyak yang berasal dari luar daerah, salah satunya mahasiswa Minangkabau yang berasal dari daerah Sumatera Barat. Dari data sementara dapat diketahui jumlah mahasiswa Minangkabau yang kuliah di Universitas Malikussaleh sebanyak 300 orang. Khususnya pada Fakultas Ilmu Sosial dan Ilmu Politik berjumlah 40 orang (sumber: Data Anggota IMAMI Lhokseumawe, 2018).

Ketika menuntut ilmu di Tanoh Rencong, tentunya mereka sudah memiliki stereotip masing-masing terhadap suku Aceh. Stereotip merupakan upaya seseorang dalam memahami lingkungannya. Stereotip adalah citra yang kaku mengenai suatu kelompok atau budaya yang dianut tanpa memperhatikan kebenaran citra tersebut. Berkembangnya stereotip dapat menyebabkan terhambatnya komunikasi antarbudaya mahasiswa Minangkabau dengan mahasiswa suku Aceh maupun dengan suku lainnya. Stereotip tersebut bisa saja menjadi penilaian negatif terhadap suku Aceh. Apabila stereotip tersebut benar adanya tentunya tuduhan tersebut secara langsung akan tertuju pada semua orang bersuku Aceh tanpa terkecuali.

Dari hasil pra observasi dan wawancara terhadap seorang informan asal Minangkabau yang berinisial MDS, mahasiswa Semester 10, menceritakan bagaimana stereotip yang dimilikinya terhadap mahasiswa suku Aceh pada saat masih berada di Semester 2. Pada tahap pengenalan, stereotip suku Aceh menurut informan: (1) mahasiswa Aceh berwatak kasar, yang dilihat dari cara mereka berkomunikasi. MDS menganggap komunikasi yang terjadi pada mahasiswa suku Aceh saat berbicara biasa terlihat seperti orang yang sedang marah karena intonasi yang mereka gunakan di saat berdialog cenderung tinggi; (2) berwatak keras, watak keras bukan berarti menyukai kekerasan. Menurut informan mahasiswa Aceh terkenal keras dengan apa yang mereka yakini, sehingga terkesan seperti keras kepala; (3) egois, namun mahasiswa suku Aceh juga dianggap kuat agama dengan julukan mereka sebagai Serambi Mekah, serta menjunjung tinggi adat dan agama mereka.

Dengan latar belakang tersebut, peneliti ingin melakukan studi mengenai stereotip pada suku Aceh yang dikhususkan pada mahasiswa dengan tujuan untuk terciptanya toleransi antar budaya dan meminimalisir kesalahpahaman dan citra yang terlalu kaku terhadap mahasiswa suku Aceh. Stereotip yang bisa dilihat dari segi pergaulan, kepribadian, penampilan, serta sikap dan 
tingkah laku mahasiswa suku Aceh oleh mahasiswa suku Minangkabau di Fakultas Ilmu Sosial dan Ilmu Politik, maka penulis ingin melakukan penelitian langsung tentang "Stereotip Mahasiswa Minangkabau terhadap Mahasiswa Suku Aceh".

Beberapa studi yang terkait dengan tema stereotip antar suku pernah dilakukan sebelumnya oleh Rosihan (2012) di Provinsi Sumatera Selatan, yaitu antara suku Komering dan suku Jawa. Dalam menjawab masalah penelitiannya, Rosihan menggunakan pendekatan kategorisasi diri. Sementara studi Farhani (2016) melihat stereotip antara masyarakat suku Sunda dengan suku Jawa. Teori kognitif digunakan sebagai titik tolak pendekatan. Kedua studi sebelumnya memiliki perbedaan dengan penelitian ini karena peneliti menggunakan pendekatan interaksionisme simbolik.

\section{Interaksionisme Simbolik}

Dalam perspektif interaksionisme simbolik, Mead menekankan simbol atau teks sebagai representasi dari pesan yang disampaikan kepada publik (Nasrullah, 2012). Mulyana \& Rakhmat (2010) menjelaskan bahwa para penganut interaksionisme simbolik tertarik pada cara manusia menggunakan simbol-simbol yang mempresentasikan apa yang mereka maksudkan untuk berkomunikasi dengan sesamanya, dan juga pengaruh yang ditimbulkan dari penafsiran atas simbol-simbol ini terhadap perilaku pihak-pihak yang terlibat dalam interaksi sosial. Esensi teori interaksi simbolik ini yaitu komunikasi atau pertukaran simbol yang diberi makna. Teori ini menjelaskan lingkungan kelompok yang memperlihatkan simbol-simbol memberikan pengaruh terhadap penilaian individu sehingga akan ada kecenderungan untuk melakukan tindakan yang sama dengan kelompok.

Dari penjelasan di atas dapat kita simpulkan bahwa penilaian seseorang terhadap suatu kelompok berdasarkan lingkungan sekitar. Tentunya perbedaan latar belakang kebudayaan menjadi pertimbangan bagi kedua pihak dalam berinteraksi (Littlejohn \& Foss dalam Rumondor, et al., 2014). Stereotip yang tercipta dari mahasiswa etnis Minangkabau terhadap mahasiswa suku Aceh dilatarbelakangi oleh interaksi mereka yang kemudian digeneralisasikan baik itu positif maupun negatif dapat berdampak ke seluruh mahasiswa suku Aceh yang kenyataannya tidak semua suku Aceh memiliki kategori seperti yang distereotipkan. Berdasarkan teori interaksi simbolik, peneliti melihat bahwa stereotip yang dimiliki oleh mahasiswa Minangkabau terhadap mahasiswa suku Aceh berdasarkan pengamalan yang diperoleh dari interaksi mereka di lingkungan sekitar dan juga berdasarkan simbol-simbol yang diperlihatkan oleh mahasiswa suku Aceh tersebut.

116 | Jurnal Ilmu Sosial dan Ilmu Politik Malikussaleh (JSPM) Volume 1 Nomor 2 Tahun 2020 


\section{Komunikasi Antarbudaya}

Menurut Stewart (1974) dalam Daryanto \& Rahardjo (2016) "komunikasi antarbudaya adalah komunikasi yang terjadi dalam kondisi yang menunjukkan adanya perbedaan budaya seperti bahasa, nilai-nilai, adat, dan kebiasaan”. Senada dengan itu, Liliweri (2003) mendefinisikan komunikasi antarbudaya sebagai proses pertukaran pikiran dan makna antara orang-orang berbeda budaya. Berdasarkan penjelasan tersebut, komunikasi antarbudaya tidak akan terjadi jika orang yang berkomunikasi memiliki kesamaan dalam segi budaya. Interaksi yang terjadi dalam komunikasi antar budaya dilakukan dengan cara menggunakan bahasa nasional (bahasa Indonesia). Proses komunikasi yang terjadi dalam komunikasi antarbudaya, pada hakikatnya sama dengan proses komunikasi yang lain, yaitu proses yang interaktif dan transaksional secara dinamis (Liliweri, 2003). Proses komunikasi antarbudaya melibatkan sejumlah unsur diantaranya komunikator, komunikan, pesan, media, dan efek atau umpan balik (Liliweri, 2003; Nasrullah, 2012). Mahasiswa Universitas Malikussaleh tidak berasal dari Aceh saja, melainkan dari berbagai daerah. Beragamnya kebudayaan di tiap-tiap daerah di Indonesia memungkinkan banyak stereotip yang muncul.

\section{Stereotip}

Stereotip menunjuk pada suatu keyakinan yang terlalu digeneralisasikan, terlalu dibuat mudah, disederhanakan, atau dilebih-lebihkan mengenai suatu kategori atau kelompok orang tertentu (Daryanto \& Rahardjo, 2016). Stereotip terbentuk berdasarkan pengalaman interaksi dengan individu lain atau kelompok individu tertentu (Juditha, 2015). Ketika kita berkomunikasi dengan orang dari suku, agama atau ras lain, kita dihadapkan dengan sistem nilai dan aturan yang berbeda. Sulit memahami komunikasi mereka bila kita sangat etnosentrik. Melekat dalam etnosentrisme ini adalah stereotip, yaitu generalisasi atas kelompok orang (suku, agama, ras) dengan mengabaikan perbedaan-perbedaan individual (Sihabudin, 2013).

Peneliti sendiri melihat stereotip merupakan gambaran atau keyakinan yang dimiliki seseorang terhadap suatu kelompok berdasarkan pengalaman pribadi maupun orang di sekitar. Stereotip yang berkembang bisa saja menjadi penilaian negatif terhadap mahasiswa suku Aceh yang apabila ditemukan kebenaran akan stereotip tersebut tentunya akan tertuju langsung pada seluruh suku Aceh tanpa terkecuali. Padahal belum tentu semua individu mengalami sebagaimana yang distereotipkan. Begitupun dengan stereotip positif, juga dapat menimbulkan hal negatif karena dapat menghasilkan harapan yang berlebihan terhadap suatu etnik.

117 | Jurnal Ilmu Sosial dan Ilmu Politik Malikussaleh (JSPM) Volume 1 Nomor 2 Tahun 2020 
Selain itu, stereotip juga mempunyai pengaruh terhadap komunikasi antarbudaya. Pertama, stereotip dapat menyebabkan tidak terjadinya komunikasi antarbudaya. Stereotip negatif yang kuat menyebabkan seseorang lebih memilih menjauh dan tidak berinteraksi dengan kelompok tersebut. Kedua, stereotip cendrung menghasilkan hal-hal negatif yang dapat mempengaruhi kualitas dan intensitas interaksi. Ketiga, jika stereotip sangat mendalam akan menimbulkan diskriminasi terhadap kelompok yang tidak disukai tersebut. Menurut Daryanto \& Rahardjo (2016) stereotip muncul karena dipelajari. Begitupun dengan interaksi yang terjadi antara mahasiswa Minangkabau dengan mahasiswa suku Aceh. Meskipun kedua suku tersebut sering berinteraksi, tidak otomatis saling pengertian terjalin diantara mereka, karena terdapat stereotip dari masing-masing budaya tersebut. Bila tidak dikelola dengan baik, kesalahpahaman antarbudaya ini akan terus terjadi dan berpotensi menimbulkan kerusuhan.

\section{METODE PENELITIAN}

Lokasi penelitian ini di Universitas Malikussaleh Kampus Bukit Indah, Fakultas Ilmu Sosial dan Ilmu Politik. Alasan penulis memilih kampus ini karena terdapat pertemuan individuindividu yang berlatarbelakang kebudayaan berbeda. Penelitian ini menggunakan metode penelitian kualitatif. Creswell dalam Ardianto (2010) menjelaskan penelitian kualitatif adalah metode penelitian yang berlandaskan pada filsafat postpositivisme dimana hasil penelitian kualitatif lebih menekankan makna daripada generalisasi. Penelitian kualitatif dipilih karena fenomena yang diamati perlu pengamatan terbuka, lebih mudah berhadapan dengan realitas, kedekatan emosional antara peneliti dan responden sehingga didapatkan data yang mendalam. Informan penelitian dalam penelitian ini adalah mahasiswa FISIP dari etnis Minangkabau yang baru berdomisili di Aceh (Semester 2) dan mahasiswa suku Aceh yang pernah satu kelas dengan mahasiswa asal Minangkabau. Alasan peneliti menggunakan subjek mahasiswa semester dua dikarenakan pada masa perkuliahan fase pengenalan akan berlangsung dalam semester satu dan dua. Dalam fase perkenalan tentunya mahasiswa yang memiliki latar belakang kebudayaan yang berbeda akan terus menggali informasi, belajar, berinteraksi, dan menyesuaikan diri dengan budaya dan lingkungan baru mereka. Peran mahasiswa suku Aceh dalam penelitian ini adalah sebagai pembanding untuk mengetahui benar atau tidaknya stereotip yang dimiliki oleh mahasiswa Minangkabau terhadap mahasiswa suku Aceh. Peneliti menggunakan jenis purposive sampling (Sugiyono, 2017) dimana kriteria informan sudah ditentukan. Sumber data primer diperoleh secara langsung di lapangan melalui observasi dan wawancara (Rakhmat, 2004) dengan didukung sumber data sekunder yang diperoleh melalui buku dan jurnal mengenai komunikasi antar budaya dan 
stereotip antar etnik. Analisis data dalam penelitian kualitatif harus dimulai sejak awal. Data yang diperoleh dalam lapangan segera dituangkan dalam bentuk tulisan dan dianalisis (Nasution dalam Ardianto, 2010).

\section{HASIL DAN PEMBAHASAN}

\section{Sterotip Mahasiswa Minangkabau terhadap Mahasiswa Suku Aceh}

Keberagaman suku dan budaya di Indonesia tidak hanya kita temui di lingkungan masyarakat, namun juga dapat ditemui pada lingkungan pendidikan seperti halnya Universitas Malikussaleh. Di sebuah universitas, mahasiswa tidak hanya berasal dari daerah sekitar universitas tersebut. Tentunya berasal dari berbagai daerah yang memiliki suku dan budaya yang berbeda dengan masyarakat Aceh, sehingga menimbulkan keberagaman dan terjadinya komunikasi antarbudaya. Dalam interaksi antara mahasiswa yang berbeda budaya, mereka memiliki penilaian sendiri terhadap kelompok yang berbeda suku dengan mereka. Biasanya stereotip sudah ada sebelum mereka datang ke Aceh, dan diperkuat oleh lingkungan dan pengalaman pribadi setelah berada di Aceh.

Stereotip merupakan suatu keyakinan terhadap suatu kelompok yang dilebih-lebihkan, stereotip yang berkembang bisa saja menjadi penilaian negatif terhadap suatu kelompok tersebut dan biasanya berdasarkan pengalaman pribadi maupun orang sekitar. Informan dalam penelitian ini berjumlah sepuluh orang, tujuh orang mahasiswa Minangkabau dan tiga orang mahasiswa suku Aceh, terdapat sepuluh pertanyaan untuk mahasiswa Minangkabau yang terdiri dari lima pertanyaan mengenai stereotip dan lima pertanyaan lainnya mengenai faktor penyebab stereotip. Untuk mahasiswa suku Aceh terdapat lima pertanyaan sebagai pembanding dari stereotip yang dimiliki oleh masyarakat Minangkabau. Dari sepuluh pertanyaan yang penulis berikan terhadap informan Minangkabau tersebut, terdapat beberapa jawaban mengenai ekspektasi yang mereka miliki sebelum menginjakkan kaki di Aceh. Pada dasarnya pengetahuan dasar mahasiswa minangkabau mengenai Aceh adalah sama, hampir semua informan menganggap suku Aceh merupakan salah satu suku yang terdapat di Provinsi Aceh yang religius dan islami. Berikut wawancara yang disampaikan oleh para informan :

"Yang awak ketahui tentang suku Aceh indak lo banyak doh, soalnyo sumber pengetauhan tentang suku Aceh cuman salamo disiko. Suku Aceh tu salah satu suku yang paling religius bahkan se-Indonesia sehingga dikenal dengan Serambi Mekah”... kalau ekspektasi... Dulu awak manyangko bakawan samo urang suku Aceh yang alim awak jadi tabaok alim, kironyo indak lo doh." (Informan J, Lhokseumawe, 12/04/2019)

119 | Jurnal Ilmu Sosial dan Ilmu Politik Malikussaleh (JSPM) Volume 1 Nomor 2 Tahun 2020 
Dari pernyataan di atas menjelaskan bahwa informan tersebut memiliki ekspektasi Aceh sesuai dengan apa yang diberitakan dan apa yang mereka ketahui sebelum menginjakkan kaki di Aceh. Informan menganggap suku Aceh yang terkenal dengan Syariat Islam memang benar-benar islami. Namun yang informan temui tidak seperti yang diduga sebelumnya. Menurut informan mahasiswa suku Aceh dan mahasiswa luar sama saja.

"Mahasiswa suku Aceh di awal saya lihat terkenal dengan Syariat Islam dan orang islam di sini banyak, Serambi Mekah pula. Ternyata yang saya duga melalui ekspektasi salah. Baik orang Aceh maupun orang luar, sama saja." (Informan R, Lhokseumawe, 13/04/2019)

Selain itu, mahasiswa suku Aceh dianggap munafik dan tidak sesuai dengan bayangan mahasiswa luar sebelum mengenal mereka, seperti penjelasan informan :

"Saya pikir orang Aceh alim-alim. Ternyata alim-alim munafik. Setiap malam keluar pacaran, tapi kalau diajak keluar, mereka menjawab tidak mau dibonceng laki-laki, padahal... (jawaban tidak dilanjutkan)." (informan F, Lhokseumawe, 22/04/2019).

Dari wawancara terhadap informan F, dapat diketahui bahwa pandangan informan terhadap mahasiswa suku Aceh sangat negatif. Berdasarkan pengalaman informan, dia menilai mahasiswa suku Aceh alim tetapi munafik karena mahasiswinya berperilaku tidak seperti simbol dan makna alim dalam bayangannya. Meskipun alim, tetapi setiap malam keluar dengan pasangan non muhrim.

Aceh dikenal dengan kota Serambi Mekah, yang menjunjung tinggi Syariat Islam, di luar Aceh sangat dihormati dan disegani, distereotipkan dengan wanita-wanita syar'i. Namun stereotip yang positif sekalipun dapat berdampak negatif karena dapat menghasilkan harapan yang berlebihan terhadap suatu etnik. Selain distereotipkan sebagai orang yang kuat agama, dalam pergaulan mahasiswa suku Aceh, dikenal tertutup bahkan berkelompok-kelompok seperti yang dijelaskan oleh informan berikutnya:

“... kebanyakan mahasiswa suku Aceh suka berkumpul berkelompok sesama mereka, jadi pergaulan dengan orang luar agak kurang. Jika berkumpul dan terdapat orang luar, dia akan mengutamakan mahasiswa Aceh terlebih dahulu." (Informan A, Lhokseumawe, 12/04/2019).

Pendapat yang sama juga disampaikan oleh informan F kepada peneliti, menurut informan: "agak susah, tidak mau membaur dengan orang luar. Berteman hanya dengan sesama mereka. Kalau sifat, mereka baik tapi tidak mau membaur.” (Informan A, Lhokseumawe, 22/04/2019)

Selain tertutup dan berkelompok, mahasiswa suku Aceh juga dianggap kurang menghargai perbedaan. Hal ini dapat dilihat saat para mahasiswa berbeda latar belakang budaya berkumpul. Di 
saat berbicara dengan sesama suku Aceh, mereka menggunakan bahasa Aceh yang tentunya tidak dimengerti oleh mahasiswa lain yang bukan berasal dari Aceh sehingga mahasiswa yang tidak mengerti dengan pembahasan mereka hanya bisa menyimak, tidak masuk dalam komunikasi tersebut. Padahal mereka sedang duduk bersama dan membahas topik yang sama seperti yang diungkapkan oleh informan:

"Ada beberapa teman yang kurang menghargai perbedaan yang ada di kampus. Soalnya kan kampus bukan hanya terdiri dari orang Aceh aja. Masih banyak kawan-kawan yang di saat kita berkumpul duduk bersama masih menggunakan bahasa daerah... tidak memberitahu apa arti yang mereka bicarakan... sehingga seakan-akan kita tidak dianggap saat itu.” (Informan J, Lhokseumawe, 12/04/2019)

Selain itu, terkadang dalam komunikasi dengan mahasiswa suku Aceh terdapat salah paham atau salah mengerti dalam penuturan bahasa diantara mahasiswa Aceh dengan mahasiswa Minangkabau. Salah paham dipicu karena ketidaktahuan mahasiswa Minangkabau dengan bahasa Aceh dan juga mahasiswa Aceh sendiri tidak memberitahu arti ucapan mereka. Tentu muncul anggapan dari mahasiswa Minangkabau prasangka atau pikiran bahwa mereka sedang dibicarakan oleh mahasiswa Aceh, entah itu positif maupun negatif.

Selanjutnya, dalam keseharian di kampus mahasiswa suku Aceh terlalu membanggakan diri bahwa mereka adalah pribumi, menganggap lebih berkuasa dan kurang menghargai pendatang seperti ketika berkumpul menggunakan bahasa Aceh, bahkan jika berbicara menggunakan bahasa Indonesia dengan gaya yang sok dan memerintah, seperti penjelasan berikut:

"Tiap orang pasti memiliki sifat yang beragam cuman ada beberapa mahasiswa yang mantap dalam pergaulan yang setelah berbicara menggunakan bahasa Aceh kemudian dijelaskan dengan bahasa Indonesia. Namun ada juga mahasiswa yang terlalu membanggakan kalau mereka pribumi, menganggap mereka berkuasa dan kurang menghargai pendatang. Seperti ketika berkumpul menggunakan bahasa Aceh. Kalaupun memakai bahasa Indonesia dengan gaya yang sok dan memerintah. Padahal derajat kita sama, mahasiswa." (Informan J, Lhokseumawe, 12/04/2019)

Dalam pergaulan sehari-hari dilingkungan kampus mahasiswa suku Aceh terlihat seperti mempertahankan pergaulan sesama putra daerah. Kurang berkomunikasi dengan suku pendatang. Memiliki karakteristik yang keras, egois dan mementingkan diri sendiri. Seperti yang dijelaskan oleh informan berikut :

“... menurut saya, kalau mayoritasnya tidak tertutup, cuman kalau minoritasnya mempertahankan pergaulan sesama putra daerah. Jarang berbicara dengan suku pendatang. Kurang pergaulan gitu. Tapi kalau dilihat mereka agak keras, egois, lebih mementingkan diri sendiri." (Informan D, Lhokseumawe, 14/04/2019)

121 | Jurnal Ilmu Sosial dan Ilmu Politik Malikussaleh (JSPM) Volume 1 Nomor 2 Tahun 2020 
Berdasarkan stereotip negatif yang dimiliki oleh mahasiswa Minangkabau, beberapa diantaranya dibantah oleh mahasiswa suku Aceh. Namun, beberapa stereotip tersebut memang benar adanya walaupun tidak semua mahasiswa Aceh seperti itu, seperti yang dijelaskan oleh informan berikut:

“... kalau watak keras, memang sih orang Aceh wataknya keras. Suka berkelompok mungkin kalau lagi di lingkungan rame-rame kita kan beda-beda suku ya, jadi mungkin kami yang orang Aceh ini belum berani berkawan sama orang luar. Awalnya emang mungkin kami tertutup tapi lama kelamaan bakalan saling sharing-sharing. Mengenai tidak mencerminkan Serambi Mekah saya kurang setuju sih. Mungkin memang ada, tapi kita nggak bisa pukul rata semuanya seperti itu. Kalau tidak menghargai perbedaan, sepertinya enggak deh. Karna menurut saya orang luar yang masuk ke lingkungan baru harus mengikuti adat dan tata krama yang ada di lingkungan tersebut... jadi kami menghargai kok. Dan lagi dalam segi bahasa yang mungkin orang luar tidak merasa dihargai, mungkin ini karena kebiasaan berbicara, keenakan aja gitu kalau udah jumpa sama anak Aceh ya otomatis pakek bahasa Aceh. Sebenarnya sih anak Minang juga seperti itu jika mereka bertemu sesama mereka pasti juga spontan berbicara dengan bahasa mereka bukan bahasa Indonesia. Stereotip mengenai genit, itu sebenarnya tergantung pribadi orang sih, pun di daerah lain pasti juga begitu bukan cuman di Aceh.” (Informan M, Lhokseumawe, 06/07/2019)

Penilaian mahasiswa Minangkabau mengenai sifat dan karakteristik mahasiswa suku Aceh, pada dasarnya bersifat umum dan tergantung kepribadian orang yang mereka jumpai. Hanya saja mahasiswa Minangkabau yang berinteraksi dengan satu atau dua orang mahasiswa suku Aceh menganggap bahwa semua mahasiswa suku Aceh itu sama, sehingga terciptalah stereotip mengenai mahasiswa suku Aceh. Begitupun dengan stereotip positif, informan M beranggapan bahwa Aceh sekarang memang hampir sama dengan daerah luar. Berikut hasil petikan wawancara:

“... kalau baik itu, tergantung orang ya. Cuman kalau religius itu karena Serambi Mekah walaupun itu dulunya. Kalau sekarang kan gak terlalu, udah sama aja Aceh, Medan, udah sama aja gitu. Karena dasarnya Aceh emang terkenal dengan keagamaannya mungkin masih ada gitu religiusnya. Kalau kita keluar Aceh orang luar pun juga menilai kalau kita pinter ngaji, gitu orang nilai orang Aceh. Dulu emang dikenal Aceh ini Serambi Mekah, gak tau sampai kemari eh sama pun banyak juga yang pakek celana jeans bahkan parah." (Informan M, Lhokseumawe, 06/07/2019)

Setuju dengan pernyataan di atas itu, menurut informan $\mathrm{F}$ keadaan orang Aceh yang religius, menjunjung tinggi Syariat Islam, dan taat agama sudah mulai memudar di Aceh seperti dijelaskan:

“... saya rasa emang benar itu, apalagi mengenai adat isitiadat emang masih dijalankan seperti kenduri blang masih ada sampe sekarang. Masalah religius dan Syariat Islam memang iya tapi udah memudar sekarang mungkin karena pemerintah yang kurang perhatian. Kayak di kampung saya ada dua pegawai Syariat Islam tapi seperti menutup mata kalau ada yang melanggar misal seperti anak perempuan yang memakai pakaian ketat, 
emang iya dirazia tapi gak tentu razianya. Yang katanya orang yang udah kenak sekali kalau kenak sekali lagi akan dikasih sanksi yang lebih berat, tapi gak ada. Padahal kita punya Qanun, dan orang ini melihat tetapi seperti membiarkan gitu.” (Informan F, Lhokseumawe, 06/07/2019)

\section{Faktor yang Menentukan Terbentuknya Stereotip Mahasiswa Minangkabau terhadap Mahasiswa Suku Aceh}

Berdasarkan hasil wawancara dengan beberapa informan, penyebab stereotip yang mereka miliki disebabkan oleh penilaian orang tua atau keluarga mereka mengenai suku Aceh. Seperti yang dijelaskan oleh informan berikut ini:

"Pesan orang tua tentang mahasiswa suku Aceh, jangan terlalu dekat. Karena kata teman ibu saya, takutnya mereka lunak di awal, nanti kalau sudah didapatkan atau kita menjadi istri mereka jadi susah pulang, harus menetap disini." (Informan K, Lhokseumawe, 13/04/2019).

Berbeda dengan informan $\mathrm{K}$, keluarga informan yang informan A justru menginginkan agar informan dekat dan bergaul dengan mahasiswa suku Aceh. Berikut hasil wawancara:

"Sebelum datang ke Aceh banyak orang-orang di kampung yang bilang, kalau di Aceh harus baik-baik karena orang Aceh juga baik... kalau bisa pulang-pulang dengan orang Aceh. Karena di luar sana Aceh terkenal dengan provinsi yang islami di Indonesia. Intinya dekat-dekat dengan orang Aceh, karena Aceh juga bagian Melayu seperti kita". (Informan A, Lhokseumawe, 12/04/2019).

Selain stereotip mengenai sifat, Aceh juga dikenal dengan ganja. Tidak bisa dipungkiri bahwa di luar Aceh nama provinsi Aceh itu sendiri selalu dikaitkan dengan ganja. Hal ini disampaikan oleh orang tua informan sebagai nasehat sebelum berkuliah di Aceh, berikut hasil wawancara:

“... Pasan urang tuo, hati-hati ganjo keceknyo..." (Informan F, Lhokseumawe, 22/04/2019).

“... Hati-hati, jangan sampai terbawa-bawa berteman dengan orang Aceh. Berteman dengan orang Aceh cukup sampai di jalan aja, jangan sampai dibawa ke dalam. Semua orang itu tidak sama, jadi kalau berteman harus milih-milih. Apalagi di Aceh, terkenal ganja. Walaupun gak ada kelihatan...." (Informan D, Lhokseumawe, 13/04/2019)

Faktor lain penyebab terbentuknya stereotip mahasiswa Minangkabau terhadap mahasiswa suku Aceh adalah melalui pengalaman pribadi dan lingkungan sekitar mereka. Berdasarkan pengalaman pribadi, para informan menceritakan bagaimana pengalaman mereka selama berteman dan berinteraksi dengan mahasiswa suku Aceh. Menurut salah seorang informan, mahasiswa suku Aceh dinilai pemalas dan tidak mau bekerjasama. Berikut hasil wawancara: 
“... kalau soal pengalaman menarik, asyik berkumpul dengan mahasiswa suku Aceh. Tapi, mahasiswa suku Aceh sedikit pemalas orangnya, jadi kita pun juga terbawa-bawa arus. Kalau ada tugas kelompok mereka tidak mau bekerjasama." (Informan A, Lhokseumawe, $12 / 04 / 2019)$.

Dalam keseharian, pengalaman yang didapatkan informan ketika berkumpul bersama mahasiswa suku Aceh, mahasiswa Minangkabau merasa seperti tidak dianggap dalam perkumpulan mahasiswa tersebut karena mahasiswa Aceh lebih sering menggunakan bahasa Aceh dibandingkan Bahasa Indonesia. Seperti penjelasan informan berikut:

“... pergaulannya kurang menyenangkan. Pernah duduk bersama orang Aceh tapi mereka asyik berbicara dengan bahasa Aceh, seperti tidak dipedulikan...." (Informan J, Lhokseumawe, 12/04/2019).

Salah seorang informan menilai, sebagian mahasiswa suku Aceh mau mengajarkan bahasa Aceh. Pengalaman itu dianggap menarik bagi informan. Dalam berinteraksi, informan menjaga komunikasi dengan mahasiswa suku Aceh karena informan pernah mendengar pepatah Aceh "Orang Aceh jangan sampai dibuat tersinggung, jangankan nasi yang masih bisa dimakan nasi basi pun tidak akan diberi”, sehingga informan memang diharuskan untuk menjaga sikap dalam bergaul dengan mahasiswa suku Aceh. Dari pepatah tersebut dapat kita lihat bahwasanya karakteristik orang Aceh adalah keras.

Keras yang dimaksud di sini adalah keras dengan pendapat mereka sehingga terkesan egois. Begitupun dengan informan lainnya, berdasarkan hasil wawancara para informan menjelaskan bahwa mereka mengontrol kata-kata dan saling menjaga dalam berkomunikasi. Menurut informan suku Aceh, stereotip mahasiswa Minangkabau diperoleh melalui interaksi yang terjadi diantara kedua suku. Perubahan penilaian mahasiswa Minangkabau mengenai mahasiswa suku Aceh tidak mencerminkan Serambi Mekah dapat dimaklumi karena mahasiswa Miangkabau melihat dan menilai bagaimana mahasiswa suku Aceh selama berada di Aceh. Berikut hasil wawancara:

“... mungkin karena orang luar Aceh tahunya kami cewek-cewek Aceh solehah, eh taunya sama kayak di sana. Mungkin karena denger dari orang sih. Gak pernah lihat gimana kondisinya. Mungkin kalau saya denger dari orang Medan kan cerita tentang anak Medan anaknya berandal-berandal. Pas saya ke sana sama juga, gitukan...” (M, Lhokseumawe, 06/07/2019).

Selain melakukan pengumpulan data melalui wawancara dengan informan, peneliti juga melakukan observasi atau pengamatan secara langsung terhadap interaksi yang terjadi antara mahasiswa suku Aceh dengan mahasiswa Minangkabau. Peneliti melakukan pengamatan di sekitar bangunan Fakultas Ilmu Sosial dan Ilmu Politik Universitas Malikussaleh seperti kelas dan kantin. Berdasarkan pengamatan peneliti menemukan bahwa terlihat mahasiswa suku Aceh yang suka 
berkelompok yang terkadang ada bercampur dengan mahasiswa Minangkabau. Di saat berbaur dengan mahasiswa suku lain khususnya mahasiswa Minangkabau mereka tetap menggunakan bahasa daerah dengan sesama mereka yang tentunya komunikasi antarbudaya tidak akan berjalan lancar dikarenakan bahasa yang mereka gunakan bukan bahasa nasional yang dimengerti oleh mahasiswa Minangkabau. Menurut informan, mahasiswa Aceh di saat bertemu dengan mahasiswa Aceh lainnya dengan spontan berbicara menggunakan bahasa mereka, bukan karena tidak menghargai mahasiswa luar. Seperti penjelasan berikut:

“...Mengenai tidak menghargai perbedaan itu karena kami sesama Aceh nyamannya seperti itu menggunakan bahasa kami. Tapi kalau lagi ngumpul sama kawan-kawan ya spontan aja berbicara dengan bahasa Aceh. Untuk mahasiswa luar kalau kita udah tinggal di tempat yang baru kita kan harus berbaur, kita selaku orang baru belajar budayanya dan bahasanya walaupun gak mungkin langsung bisa, setidaknya mengerti dengan bahasa kami..." (M, Lhokseumawe, 06/07/2019).

Peneliti sesekali melihat interaksi yang terjadi antara mahasiswa Aceh dengan mahasiswa Minangkabau saat berpapasan, bahkan interaksi yang terjadi selama berada di kelas yang terlihatnya hanya sekedar dan seperlunya saja. Begitupun interaksi yang terjadi di luar lingkungan kampus seperti di kos, mahasiswa suku Aceh terlihat agak tertutup dan kurang berbaur dengan mahasiswa suku lain khususnya mahasiswa Minangkabau dan terlihat lebih mementingkan dan mendahulukan orang yang satu suku dengan mereka. Hal ini dibenarkan oleh informan mahasiwa suku Aceh. Berikut hasil wawancara :

"Dan juga di saat mahasiswa Aceh bertemu emang spontan berbahasa Aceh, terkadang kami secara tidak sadar jika bertiga dengan orang luar dan satu diantaranya adalah anak Aceh ya spontan kami mendahulukan anak Aceh karena bahasa tadi." (F, Lhokseumawe, 07/07/2019).

Mahasiswa suku Aceh dinilai memprioritaskan sesama suku Aceh di saat berkomunikasi dengan mahasiwa luar tidak dibantah oleh informan. Sebagian orang Aceh menurut Faisal malu dan tidak percaya diri dalam berbahasa Indonesia sehingga mahasiswa luar menilai hal itu dengan pemaknaan lain.

Media juga turut memberikan andil dalam munculnya stereotip mahasiswa Minangkabau terhadap mahasiswa suku Aceh. Aceh yang memiliki sejarah kelam mengenai konflik beberapa tahun silam, membuat stereotip tentang mereka semakin bertambah. Untuk lebih jelasnya, berikut hasil wawancara terhadap informan:

"Khususnya orang terdekat yang belum pernah berrgaul dengan suku Aceh yang hanya mengetahui dari TV beranggapan suku Aceh alim, religius, pengetahuan agama yang luar biasa, saat mengaji memiliki suara yang bagus, dianggap luar biasa. Aceh juga terkenal 
dengan GAM, jadi orang Aceh menurut orang terdekat suit untuk menerima suku luar Aceh.” (Informan J, Lhokseumawe, 12/04/2019).

\section{Pembahasan}

Berdasarkan hasil pengamatan, setiap mahasiswa Minangkabau di Fakultas Ilmu Sosial dan Ilmu Politik Universitas Malikussaleh memiliki persepsi yang berbeda terhadap mahasiswa suku Aceh. Setiap individu memiliki penilaian dan stereotip sendiri sesuai dengan pengalaman pribadi yang mereka rasakan maupun pengaruh lingkungan sosial seperti keluarga. Hal ini sangat berkaitan dengan teori interaksionisme simbolik. Teori ini menyatakan bahwa lingkungan kelompok memperlihatkan simbol-simbol yang memberikan pengaruh terhadap diri individu. Dari penjelasan tersebut, dapat dipahami bahwa penilaian seseorang terhadap suatu kelompok berdasarkan lingkungan sekitar. Stereotip yang dimiliki oleh mahasiswa Minangkabau dilatarbelakangi oleh interaksi mereka dengan mahasiswa suku Aceh.

Stereotip merupakan generalisasi tentang kelompok orang yang sangat menyederhanakan realitas. Biasanya orang yang memiliki stereotip, susah untuk mengubah pandangannya terhadap orang yang distereotipkan, kecuali individu tersebut berupaya untuk menghilangkan stereotip yang ada pada dirinya. Beberapa faktor yang dapat mendukung terjadinya perubahan pada stereotip tersebut adalah : (1) status sosial yang sama, (2) kontak pribadi yang lebih intim, (3) imbalan atau hasil yang memuaskan, (4) Partisipasi bersama dalam kegiatan penting untuk tujuan yang sama. Sebegaimana menurut Daryanto \& Rahardjo (2016) terdapat 4 dimensi dari stereotip yaitu :

\section{a. Arah (Direction) pada Dimensi Stereotip}

Arah dalam dimensi stereotip merujuk pada arah penilaian apakah positif atau negatifnya penilain individu terhadap kelompok atau suku tertentu. Dalam penelitian ini terdapat stereotip positif dan negatif yang dimiliki oleh mahasiswa Minangkabau terhadap mahasiswa suku Aceh. Namun didominasi oleh stereotip negatif. Berdasarkan hasil penelitian, peneliti menemukan beberapa stereotip yang dimiliki oleh mahasiswa Minangkabau terhadap mahasiswa suku Aceh. Beberapa stereotip sudah ada sebelum para informan berada/kuliah di Universitas Malikussaleh dan beberapa lainnya didapatkan setelah berada dan berinteaksi dengan mahasiswa Aceh itu sendiri.

Pada umumnya stereotip yang dimiliki mahasiswa Minangkabau terhadap mahasiswa suku Aceh terdapat stereotip positif dan negatif. Stereotip positif yang terbentuk yaitu mahasiswa suku Aceh yang dikenal alim, religius, kuat agama, menjunjung tinggi syariat islam, taat ibadah, pakaian

126 | Jurnal Ilmu Sosial dan Ilmu Politik Malikussaleh (JSPM) Volume 1 Nomor 2 Tahun 2020 
syar'i, dan hal-hal lainnya yang berbau islami serta sangat menghormati adat istiadat. Tetapi, terdapat stereotip negatif yang mendominasi yaitu mahasiswa suku Aceh dianggap suka berkelompok, tidak mencerminkan "Serambi Mekah", genit, egois, kasar, dan pelit. Tetapi realitasnya mahasiswa suku Aceh yang berada di Universitas Malikussaleh tidak seperti yang mereka (para informan) bayangkan sebelumnya. Selanjutnya informan dalam penelitian ini juga memiliki stereotip bahwa mahasiswa suku Aceh memiliki perilaku tertutup dan kurang menghargai perbedaan. Selain itu, mahasiswa Aceh dianggap hanya beriteraksi dengan sesama mereka. Berdasarkan hasil wawancara, berikut stereotip yang dimiliki oleh mahasiswa Minangkabau:

Tabel 1. Stereotif Mahasiswa Minangkabau terhadap Mahasiswa Suku Aceh

\begin{tabular}{|c|c|c|}
\hline No & Positif & Negatif \\
\hline 1 & Religius, islami & $\begin{array}{l}\text { Sombong, sok berkuasa, dan membanggakan } \\
\text { diri sebagai pribumi }\end{array}$ \\
\hline 2 & Baik, mudah akrab & Kurang memprioritaskan suku lain \\
\hline 3 & Tidak pamrih, suka membantu & Sirik dan susah berbagi \\
\hline 4 & Rajin beribadah & Suka berkumpul dengan sesama mereka \\
\hline 5 & $\begin{array}{l}\text { Saling menghargai, menghormati adat } \\
\text { istiadat }\end{array}$ & $\begin{array}{l}\text { Munafik, tidak mencerminkan Serambi } \\
\text { Mekah }\end{array}$ \\
\hline 6 & \multirow[t]{5}{*}{ e } & Pemalas, berwatak keras \\
\hline 7 & & Tidak menghargai perbedaan \\
\hline 8 & & Egois, susah membaur \\
\hline 9 & & Pelit, suka memandang status \\
\hline 10 & & Identik dengan ganja \\
\hline
\end{tabular}

Sumber: data diolah dari hasil penelitian, 2019.

Pada dasarnya mahasiswa Minangkabau berteman baik dengan mahasiswa suku Aceh, hanya saja mahasiswa suku Aceh seperti memberikan batas antara mereka dengan mahasiswa luar, khususnya mahasiswa suku Minangkabau. Terkadang beberapa mahasiswa suku Aceh cenderung hanya berinteraksi dengan sesama mereka. Menurut beberapa informan, saat mahasiswa suku Aceh berkumpul dengan mahasiswa suku lain mereka tetap menggunakan bahasa daerah dengan sesama mereka. Mahasiswa suku Minangkabau menganggap bahwa mereka tidak dihargai atau tidak dianggap keberadaannya dalam perkumpulan tersebut. Namun pada kondisi tertentu, bila ada beberapa mahasiswa suku Aceh berbicara dengan sesama mereka menggunakan bahasa daerah, maka mereka akan menerjemahkan apa yang mereka bicarakan pada mahasiswa lain yang tidak mengerti pembahasan mereka. 
Berdasarkan penjelasan mahasiswa Aceh, penggunaan bahasa daerah di saat mereka berkumpul di suatu kelompok yang didominasi oleh suku mereka, terjadi secara otomatis tanpa disadari oleh mahasiswa suku Aceh. Selain itu, kecendrungan mahasiswa Aceh menggunakan bahasa daerah disebabkan oleh kurangnya rasa percaya diri mahasiswa suku Aceh dalam menggunakan bahasa Indonesia. Dari hal tersebut, dapat diketahui terjadinya kesalahpahaman antar kedua suku yang disebabkan oleh bahasa sehingga mahasiswa Minangkabau memiliki stereotip bahwa mahasiswa Aceh tidak menghargai mahasiswa Minangkabau. Kesalahpahaman tersebut tentunya dapat memicu terbentuknya jarak antara mahasiswa Minangkabau dengan mahasiswa suku Aceh.

Selanjutnya, mahasiswa suku Aceh dianggap suka berkelompok dan tidak suka berbaur. Beberapa informan menjelaskan bahwa interaksi mereka di luar kampus khusunya di kos dengan mahasiswa suku Aceh hanya sebatas keperluan yang dianggap penting seperti iuran listrik dan wifi. Selain itu, mahasiswa suku Aceh lebih suka mengurung diri di kamar. Berdasarkan observasi yang peneliti lakukan, terdapat mahasiswa suku Aceh yang lebih cenderung menyukai berkomunikasi dengan sesama suku. Mereka beralasan memiliki kedekatan yang lebih dari segi bahasa dan kebudayaan sehingga sulit untuk mahasiswa luar seperti mahasiswa Minangkabau untuk mendekati mahasiswa suku Aceh.

Selanjutnya, Aceh yang dulunya dikenal karena Gerakan Aceh Merdeka (GAM) yang identik dengan kata konflik tentunya menjadi satu kekhawatiran bagi para pendatang yang tidak mengetahui sejarah Aceh. Di luar Aceh, keberadaan GAM di Aceh dipandang sebagai orang yang berwatak keras dan egois. Beberapa informan dalam penelitian ini juga memiliki stereotip yang sama mengenai watak mahasiswa suku Aceh yang dianggap egois dan menganggap dirinya berkuasa dan membanggakan bahwa mereka adalah pribumi, suka memerintah, dan kurang menghargai pendatang.

\section{b. Ketepatan pada Dimensi Stereotip}

Dalam stereotip yang dimiliki mahasiswa Minangkabau terhadap mahasiswa suku Aceh, tentunya terdapat beberapa stereotip yang benar maupun yang tidak menggambarkan kebenaran. Dilihat dari segi ketepatan, stereotip yang dimiliki mahasiswa Minangkabau terhadap mahasiswa suku Aceh dapat dilihat dari penilaian mereka yang digeneralisasikan terhadap semua mahasiswa suku Aceh. Perlu diketahui bahwa stereotip yang terbentuk bisa saja dikarenakan mahasiswa Minangkabau hanya berinteraksi dengan dua atau beberapa orang mahasiswa suku Aceh. Di saat informan mempelajari sifat dan karakteristik mahasiswa suku Aceh, secara tidak sadar informan 
menganggap semua mahasiswa suku Aceh memiliki sifat dan karakteristik yang sama. Beberapa dari stereotip informan tentunya tidak menggambarkan kebenaran. Namun, stereotip juga dapat berkembang dari penajaman dan generalisasi yang berlebihan. Berdasarkan hasil wawancara dengan mahasiswa suku Aceh, ketiga informan memaklumi semua hal yang distereotipkan oleh mahasiswa Minangkabau terhadap mereka. Namun, beberapa stereotip yang mereka berikan tidak sepenuhnya benar. Seperti stereotip genit yang ditujukan terhadap mahasiswa Aceh, secara tidak langsung menuduh mahasiswa suku Aceh secara keseluruhan sedangkan sifat genit tersebut juga dimiliki oleh mahasiswa lain.

\section{c. Intensitas pada Dimensi Stereotip}

Intensitas merujuk pada seberapa kuatnya keyakinan dari suatu stereotip. Semakin kuat keyakinan informan terhadap stereotip yang mereka yakini terhadap mahasiswa suku Aceh, semakin terhambatnya komunikasi yang akan berlangsung diantara kedua suku. Kuatnya keyakinan mahasiswa Minangkabau terhadap mahasiswa suku Aceh baik dalam stereotip positif maupun negatif dapat berdampak dalam kualitas dan intensitas interaksi antara kedua suku. Hal ini dapat dilihat dari hasil wawancara terhadap mahasiswa Minangkabau, informan menjelaskan bahwa ia memilih untuk tidak terlalu dekat dengan mahasiswa suku Aceh mengingat suku Aceh dinilai tidak menghargai perbedaan dan hanya bergaul dengan sesama mereka. Semakin sering mahasiswa Minangkabau mengalami hal tersebut tentunya akan semakain kuat keyakinan mereka terhadap stereotip yang mereka miliki. Selain itu, stereotip negatif yang semakin kuat menyebabkan mahasiswa Minangkabau mengurangi kemungkinan kontak dengan mahasiswa suku Aceh bahkan hal tersebut dapat menghambat komunikasi yang terjadi diantara kedua suku.

\section{d. Isi Khusus pada Dimensi Stereotip}

Hal ini terkait dengan sifat-sifat khusus mengenai mahasiswa suku Aceh. Stereotip mengenai suku Aceh dari beberapa mahasiswa Minangkabau dapat berbeda-beda. Disamping itu, isi stereotip bisa saja berubah dari waktu ke waktu. Stereotip positif sekalipun dapat berdampak negatif karena menyebabkan orang yang memiliki stereotip tersebut memiliki harapan yang berlebihan terhadap suatu kelompok atau suku yang mereka stereotipkan. Begitupun stereotip negatif, keyakinan yang digeneralisasikan, dan dilebih-lebihkan mengenai penilaian terhadap suatu

kelompok atau suku tertentu dapat menyebabkan terhambatnya komunikasi antarbudaya dan juga dapat mengurangi intensitas interaksi antara kedua suku. 
Berdasarkan wawancara menurut informan mahasiswa Minangkabau, mahasiswa suku Aceh memiliki sifat yang baik, mudah akrab, saling menghargai, suka membantu, religius, dan islami. Namun, hal positif tersebut berubah menjadi penilaian negatif seperti: sirik dan susah berbagi, tertutup, tidak menghargai perbedaan, pemalas, genit, dan tidak mencerminkan Serambi Mekah. Stereotip negatif yang mereka miliki menyebabkan mahasiswa Minangkabau membatasi pergaulan mereka dengan mahasiswa suku Aceh. Dengan kata lain, mereka hanya akan berkomunikasi seperlunya saja. Menurut informan, hubungan pertemanan mahasiswa Minangkabau dengan mahasiswa suku Aceh diatur sedemikian rupa agar tidak terlalu dekat dan tidak terlalu jauh.

Stereotip muncul karena pengaruh lingkungan. Kecenderungan seseorang dalam menstereotipkan seseorang terjadi melalui pengalaman orang lain, terutama bila orang yang memiliki stereotip tersebut tidak pernah bergaul dengan kelompok yang distereotipkan. Dalam penelitian ini beberapa informan menjelaskan keluarga cenderung memiliki stereotip terhadap mahasiswa suku Aceh. Sebelum berangkat ke Aceh informan diingatkan mengenai beberapa hal mengenai pergaulan dengan mahasiswa suku Aceh nantinya. Peran orang tua yang mempengaruhi pola pikir informan untuk menjaga jarak terhadap mahasiswa suku Aceh. Beberapa informan juga diingatkan mengenai ganja, mengingat Aceh terkenal dengan ganja dan berbagai kasus narkoba. Meskipun begitu beberapa keluarga informan lainnya mengarahkan informan untuk bergaul dan menjalin komunikasi yang baik dengan mahasiswa suku Aceh.

Selain orang tua, lingkungan tempat tinggal tentunya memiliki peran besar dalam terbentuknya stereotip terhadap mahasiswa suku Aceh. Bagaimana pergaulan mereka di kampus maupun di luar kampus dapat menjadi faktor terbentuknya stereotip terhadap mahasiswa suku Aceh seperti pergaulan antara kedua suku tersebut. Dalam interaksi mahasiswa Minangkabau dengan mahasiswa suku Aceh, pengalaman selama berinteraksi antara kedua suku telah mengubah pandangan mahasiswa suku Minangkabau terhadap mahasiswa suku Aceh. Sebelum kuliah di Aceh, mahasiswa Minangkabau memiliki penilaian yang sangat positif terhadap mahasiswa suku Aceh seperti religius, menjunjung tinggi Syariat Islam, Serambi Mekah, dan menghormati adat istiadat. Seiring dengan berjalannya waktu dan terjadinya interaksi antara kedua suku, mempengaruhi penilaian mahasiswa Minangkabau terhadap mahasiswa suku Aceh menjadi penilaian negatif.

Hal ini sesuai dengan teori interaksi simbolik yang telah dijelaskan dalam bab sebelumnya bahwa manusia bertindak terhadap manusia lainnya berdasarkan makna yang diberikan orang lain kepada mereka. Lingkungan kelompok yang memperlihatkan simbol-simbol memberikan 
pengaruh terhadap penilaian pada individu. Dari penjelasan tersebut, dapat dipahami bahwa penilaian seseorang terhadap suatu kelompok berdasarkan makna yang ditanamkan lingkungan sekitar. Stereotip yang tercipta dari mahasiswa Minangkabau terhadap mahasiswa suku Aceh dilatarbelakangi oleh interaksi mereka yang kemudian digeneralisasikan dan berdampak pada seluruh mahasiswa suku Aceh yang kenyataannya tidak semua mahasiswa suku Aceh memiliki kategori seperti yang distereotipkan.

Stereotip yang dimiliki oleh mahasiswa Minangkabau terhadap mahasiswa suku Aceh merupakan interpretasi atas dunia sekeliling mereka. Dalam konteks ini, stereotip mahasiswa Minangkabau terhadap mahasiswa suku Aceh terbentuk karena lingkungan mereka memperlihatkan simbol-simbol yang memberikan pengaruh terhadap penilaian mahasiswa Minangkabau terhadap mahasiswa suku Aceh seperti tingkah laku, sikap, dan karakteristik mahasiswa suku Aceh yang dipelajari oleh mahasiswa Minangkabau berdasarkan interaksi diantara mereka. Selain itu, lingkungan sosial seperti keluarga tentunya juga berperan besar dari penilaian tersebut. Untuk membuktikan kebenaran faktor penyebab timbulnya stereotip yang dimiliki informan mahasiswa Minangkabau, peneliti juga mewawancarai beberapa orang mahasiswa suku Aceh sebagai pembanding untuk membuktikan kebenaran stereotip yang dimiliki oleh mahasiswa Minangkabau. Mengingat stereotip bisa saja berasal dari fakta yang dilebih-lebihkan. Dari hasil wawancara terhadap informan mahasiswa suku Aceh, peneliti dapat menyimpulkan bahwa stereotip yang dimiliki mahasiswa Minangkabau memang berdasarkan fakta yang didapat berdasarkan pengalaman pribadi mahasiswa Minangkabau selama kuliah di Aceh dan hal tersebut dibenarkan oleh mahasiswa suku Aceh. Namun, tentunya penilaian tersebut tidak berlaku untuk semua mahasiswa suku Aceh karena tidak semua mahasiswa suku Aceh seperti yang distereotipkan oleh mahasiswa Minangkabau meskipun sebagian besar memang seperti itu.

Selain dari orang tua dan pengalaman pribadi, munculnya stereotip dari mahasiswa Minangkabau terhadap mahasiswa suku Aceh disebabkan oleh terpengaruhnya informan dengan media massa. Keyakinan terhadap suatu kelompok atau suku tertentu yang belum pernah dikenal dan bergaul sebelumnya tentunya didapatkan dari media massa seperti surat kabar, televisi, majalah, film, radio, buku, dan lan-lain. Selain itu, stereotip yang diketahui dari media massa didapatkan berdasarkan observasi yang penulis lakukan terhadap mahasiswa Minangkabau. sebelum datang ke Aceh mereka hanya mengenal Aceh melalui televisi dan media massa sehingga setelah datang ke Aceh apa yang informan lihat di layar kaca sangat berbeda dengan apa yang mereka temui secara nyata. Umumnya, informasi yang mereka dapatkan dari televisi dan media massa bersifat positif seperti Syariat Islam, islami dan religius. Namun, setelah berada di Aceh 
penilaian tersebut berubah seiring dengan interaksi yang mereka lakukan dengan mahasiswa suku Aceh.

\section{KESIMPULAN}

Stereotip mahasiswa Minangkabau terhadap mahasiswa Suku Aceh tidak terlepas dari interaksi yang terjadi di lingkungan kampus. Selain itu, stereotip juga didapatkan dari lingkungan sosial seperti keluarga ataupun orang terdekat. Stereotip didominasi oleh pandangan negatif diantaranya yaitu mahasiswa suku Aceh dianggap tertutup, suka berkelompok, susah membaur, tidak menghargai perbedaan, pelit, genit, egois, identik dengan ganja, sombong, dan tidak mencerminkan simbol Serambi Mekah. Namun, terdapat pula stereotip positif seperti mahasiswa suku Aceh yang kuat keyakinan agamanya, baik, religius, menjunjung tinggi syariat Islam, dan sangat menghormati adat istiadat. Adapun faktor yang mempengaruhi stereotip mahasiswa Minangkabau terhadap suku Aceh bukan sesuatu yang dibawa sejak lahir, namun muncul karena dipelajari yang diperoleh melalui:

1. Pengalaman orang terdekat, terutama bila mereka tidak mampu atau kurang bergaul dengan orang-orang yang termasuk dalam kelompok yang distereotipkan.

2. Pengalaman pribadi, setelah berinteraksi dengan satu atau dua orang mahasiswa suku Aceh, kemudian melakukan generalisasi tentang sifat maupun karakteristik yang dimiliki oleh mahasiswa suku Aceh.

3. media massa seperti surat kabar, majalah, film, radio, TV, buku, dan sebagainya, karena diasumsikan bahwa apa yang disampaikan melalui media massa bersifat faktual dan objektif.

Mahasiswa Universitas Malikussaleh terdiri dari berbagai daerah yang memiliki ragam suku dan budaya, diharapkan mahasiswa dengan latar belakang kebudayaan yang berbeda dapat menghargai perbedaan yang ada dan dapat mengurangi pikiran negatif terhadap kelompok atau suku yang berbeda dengan mereka. Terkait dengan perbedaan bahasa dalam lingkungan kampus, peneliti menyarankan agar mahasiswa yang berbeda suku tidak memaksakan kehendak dengan menggunakan bahasa yang tidak dimengerti suku lain. Bahasa sangat berpengaruh terhadap berhasil atau tidaknya komunikasi yang dilakukan. Peneliti menyarankan agar mahasiswa suku Aceh tidak membeda-bedakan ketika melakukan komunikasi dengan mahasiswa yang berbeda suku dan penulis berharap agar mahasiswa suku Aceh tidak menjadikan perbedaan bahasa menjadi suatu hambatan dan penyebab tidak berjalannya komunikasi yang efektif dengan suku lain. Penelitian ini diharapkan dapat menjadi bahan untuk menyikapi faktor terbentuknya sterotip. Bagi orang tua diharapkan dapat menghilangkan penilaian negatif yang berlebihan terhadap suatu 
kelompok/suku sebelum mengenal dan berinteraksi dengan mereka. Begitu pula mahasiswa Minangkabau yang memiliki sterotip berdasarkan pengalaman pribadi hendaknya dapat memiliki batas terhadap penilaian mereka karena stereotip yang dimiliki secara tidak langsung berdampak kepada seluruh mahasiswa suku Aceh.

\section{DAFTAR PUSTAKA}

Ardianto, E. (2010). Metodologi Penelitian Untuk Public Relations: Kuantitatif dan Kualitatif. Simbiosa Rekatama Media.

Daryanto \& Rahardjo, M. (2016). Teori Komunikasi. Gava Media.

Farhani, R. N. (2016). Stereotip Masyarakat Sunda Terhadap Masyarakat Pendatang Jawa di Kampung Nelayan Desa Teluk Kecamatan Labuan Kabupaten Pandeglang Banten. Skripsi. FISIPOL Universitas Sultan Ageng Tirtayasa.

Juditha, C. (2015). Stereotip dan Prasangka dalam Konflik Etnis Tionghoa dan Bugis Makassar. Jurnal Ilmu Komunikasi, 12(1), 87-104.

Liliweri, A. (2003). Dasar-Dasar Komunikasi Antarbudaya. Pustaka Pelajar.

Mulyana, D. \& Rakhmat, J. (2010). Komunikasi Antar Budaya: Panduan Berkomunikasi dengan Orang-Orang Berbeda Budaya. PT Remaja Rosdakarya.

Nasrullah, R. (2012). Komunikasi Antarbudaya di Era Budaya Siber. Kencana Prenada Media Group.

Rakhmat, J. (2004). Metode Penelitian Komunikasi Dilengkapi Contoh Analisis Statistik. PT. Remaja Rosdakarya.

Rosihan, A. (2012). Stereotipisasi Etnis Pribumi atas Etnis Pendatang (Studi Deskriptif Stereotip pada Etnis Komering atas Etnis Jawa: Studi Kasus di SMA Negeri 1 Martapura, OKU Timur, Sumatera Selatan). Tesis. Universitas Indonesia.

Rumondor, F. H., Paputungan, R., \& Tangkudung, P. (2014). Stereotip Suku Minahasa terhadap Etnis Papua (Studi Komunikasi Antarbudaya pada Mahasiswa Fakultas Ilmu Sosial Ilmu Politik Universitas Samratulangi. Acta Diurna Komunikasi, 3(2).

Sihabudin, A. (2013). Komunikasi Antar Budaya Satu Perspektif Multidimensi. Bumi Aksara.

Sugiyono (2017). Metode Penelitian Kuantitatif, Kualitatif dan R\&D. Alfabeta.

133 | Jurnal Ilmu Sosial dan Ilmu Politik Malikussaleh (JSPM) Volume 1 Nomor 2 Tahun 2020 